\title{
SEED GERMINATION OF ERODIUM MACROPHYLLUM (GERANIACEAE)
}

\author{
Ian G. Gillespie ${ }^{1,2}$ and Hally M. Andersen ${ }^{1}$ \\ Department of Botany and Plant Sciences, University of California, \\ Riverside, CA 92521
}

Key Words: seed germination, scarification, Erodium macrophyllum, filaree, seed dormancy.

Mechanisms that break dormancy in seeds are of interest on both an ecological level and for applied purposes when trying to maximize germination of seeds used in restoration efforts. Ecologically, understanding seed dormancy can provide insight into life-history strategies and evolutionary patterns (Templeton and Levin 1979; Baskin and Baskin 1998). For restoration studies, understanding seed biology can ultimately result in improved restoration (McDonald 1993). Unfortunately, for many species, especially those that are rare, we often lack the data necessary to understand what treatments, if any, will affect seed dormancy. We experimentally tested how 10 treatments would affect the germination of seeds from the rare native California grassland forb, Erodium macrophyllum Hook. \& Arn. (large-leaved filaree, Geraniaceae).

Erodium macrophyllum is a rare annual forb found in small populations throughout the California floristic province (Gillespie 2005). Although it was likely once more common, it has become exceedingly rare in many parts of California. It is found in exotic and native grasslands and coastal sage scrub. Like many of California's native forbs, seeds of E. macrophyllum germinate in the fall or early winter at the onset of rain and the plants grow, reproduce and then senesce in spring. We studied E. macrophyllum because previous work indicated that restoration of this species can be inhibited by poor germination (Gillespie and Allen 2004). Given that very little is known about E. macrophyllum seed dormancy we used 10 different treatments in hopes of finding at least one that may increase germination.

Treatments consisted of stratification, heat, three different concentrations of smoke water, gibberellic acid, sulfuric acid, scarification, removal of the pericarp and a control that received no treatment. These treatments were chosen because they are sometimes known to affect seed dormancy (Baskin and Baskin 1998; Montalvo et al. 2002). The pericarp removal treatment was specifically chosen because they can fall off after extensive handling of the seeds (Gillespie personal observation). The

\footnotetext{
${ }^{1}$ Present address: 181 Westminster Road, Putney, VT 05346.

${ }^{2}$ Author for correspondence, email: ian@iggsoftware. com
}

seeds came from approximately 20 plants grown in a greenhouse and the original seed source came from a population of E. macrophyllum in western Riverside County, California $\left(33.7416^{\circ} \mathrm{N}\right.$, $117.4387^{\circ} \mathrm{W}$; elevation $365 \mathrm{~m}$ ). The experiment was carried out in a laboratory where the temperature was kept between approximately $20-23^{\circ} \mathrm{C}$. For each treatment, 10 seeds were placed in a plastic Petri dish ( $9 \mathrm{~cm}$ diameter) between two pieces of filter paper. Each treatment was replicated 10 times in Petri dishes $(10$ treatments $\times 10$ replicates $=100$ Petri dishes). The filter paper was kept moist with distilled water added as needed throughout the duration of the study. Seeds were monitored every 23 days from 18 November 2002 to 15 December 2002. When a seed was found to be germinating (i.e., at least the emerging radicle was visible) it was removed from the dish. A one-way analysis of variance (ANOVA) was used to determine if the germination amounts differed between treatments. The details of each treatment are as follows:

Stratification. Seeds were placed in dry Petri dishes in a refrigerator at $9^{\circ} \mathrm{C}$ from 15 October to 15 November 2002.

Heat. Seeds were placed in glass Petri dishes in a drying oven at $40^{\circ} \mathrm{C}$ from 15 October to $15 \mathrm{No}$ vember 2002. Later seeds were transferred into plastic Petri dishes.

Smoke water. Three different dilutions of smoke water were used: 1:10, 1:100 and 1:1000 (E. Allen personal communication). The dilutions were made with distilled water and Liquid Smoke (Colgin, TX, USA). For each of the three different treatments the seeds were soaked in their appropriate diluted smoke water for 24 hrs one day before the study started.

Gibberellic acid. $5 \mathrm{ml}$ of Gibberellic acid (50 ppm) was added to each of the 10 Petri dishes when the experiment was started.

Sulfuric acid. The seeds were soaked in concentrated sulfuric acid for 60 seconds and then rinsed in distilled water before being added to Petri dishes.

Scarification. The pericarp was removed from each seed and then the seed coat was nicked with a razor blade. 


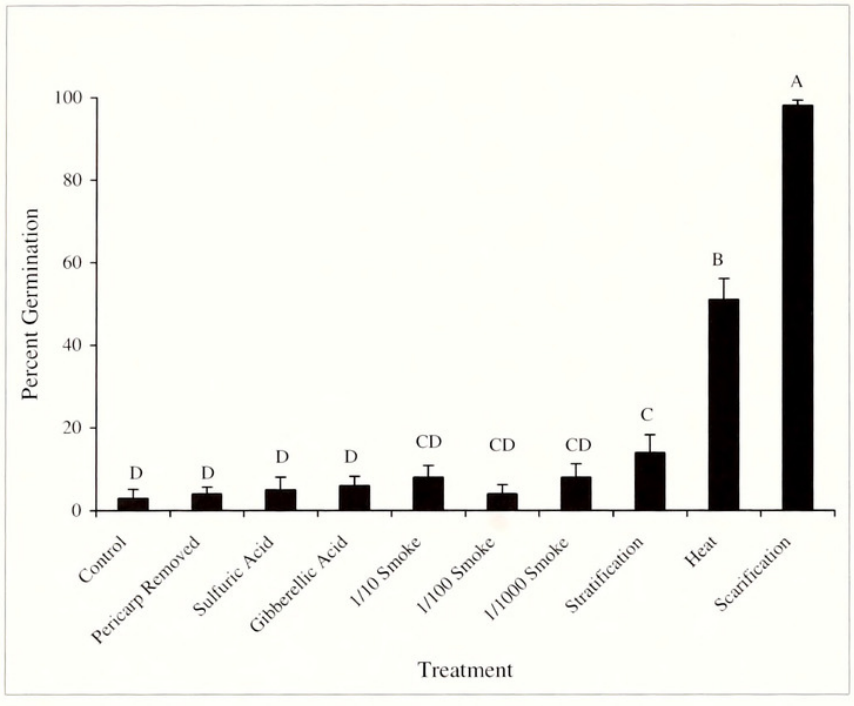

FIG. 1. Percent germination of seeds from the rare forb Erodium macrophyllum under ten different treatments. Different letters between bars indicate a significant difference $(\mathrm{P}<0.05)$. Data are means \pm one standard error, $n$ $=10$.

Pericarp removal. The pericarp was removed from each seed to control for the scarification treatment.

Control. These seeds were not manipulated except for being put in 10 Petri dishes in moist filter paper.

The scarification treatment had the greatest effect on seed germination (Fig. 1). Heat, although not as effective as the scarification treatment, increased germination by $48 \%$ compared to the control. The stratification treatment also increased germination compared to the control, sulfuric acid, pericarp removal and the 1:100 smoke water treatments. No other treatments significantly increased germination (Fig. 1).

Our results have implications for E. macrophyllum seeds in wild populations. For example, the heat treatment, although lasting for only 30 days, is similar to what a seed might experience during the hot, dry summers of California and our results suggest that such an exposure may affect subsequent germination of E. macrophyllum seeds. Given this, it is possible that the severity of summer heat may influence subsequent E. macrophyllum recruitment the following wet season. The results from the scarification treatment suggest that germination of E. macrophyllum may be enhanced by physical abrasion to the seed coat. Abrasion to the seed may occur when the seeds drill themselves into the ground using their awns which coil and uncoil in response to changing moisture levels (Gillespie personal observation). However, it is likely that this abrasion does not greatly increase germination, at least in some soil types (Gillespie and Allen 2004). If land managers and restorationists use seed to introduce E. macrophyllum at a restoration or mitigation site, heating or scarifying the seeds provides for an inexpensive and effective way to maximize germination.

\section{Literature Cited}

BAskin, C. J. And J. M. BASkin. 1998. Seeds: ecology, biogeography, and evolutionary dormancy and germination Academic Press, San Diego, CA.

Gillespie, I. G. 2005. Habitat characteristics and distribution of Erodium macrophyllum (Geraniaceae). Madroño 52:53-59.

- AND E. B. Allen. 2004. Fire and competition in a southern California grassland: impacts on the rare forb Erodium macrophyllum. Journal of Applied Ecology 41:643-652.

McDonald, A. W. 1993. The role of seedbank and sown seeds in the restoration of an English flood-meadow. Journal of Vegetation Science 4:395-400.

Montalvo, A., L. Feist-Alvey, and C. Koehler. 2002. The effect of fire and cold treatments on seed germination of annual and perennial populations of Eschscholzia californica (Papaveraceae) in southern California. Madroño 49:207-227.

Templeton, A. R. And D. A. Levin. 1979. Evolutionary consequences of seed banks. American Naturalist $114: 232-249$. 


\section{$2 \mathrm{BHL}$ Biodiversity Heritage Library}

Gillespie, Ian G and Andersen, Hally M . 2005. "SEED GERMINATION OF ERODIUM MACROPHYLLUM (GERANIACEAE)." Madroño; a West American journal of botany 52, 123-124. https://doi.org/10.3120/0024-9637(2005)52[123:sgoemg]2.0.co;2.

View This Item Online: https://www.biodiversitylibrary.org/item/185048

DOI: https://doi.org/10.3120/0024-9637(2005)52[123:sgoemg]2.0.co;2

Permalink: https://www.biodiversitylibrary.org/partpdf/169105

\section{Holding Institution}

Smithsonian Libraries

\section{Sponsored by}

Biodiversity Heritage Library

\section{Copyright \& Reuse}

Copyright Status: In Copyright. Digitized with the permission of the rights holder License: http://creativecommons.org/licenses/by-nc/3.0/ Rights: https://www.biodiversitylibrary.org/permissions/

This document was created from content at the Biodiversity Heritage Library, the world's largest open access digital library for biodiversity literature and archives. Visit BHL at https://www.biodiversitylibrary.org. 